\title{
DISCOVERY OF ALLONYX QUADRIMACULATUS (SCHALLER, 1783) (COLEOPTERA CLERIDAE CLERINAE) IN RUSSIA
}

\author{
(*) Joint Directorate of the Mordovia State Nature Reserve and National Park «Smolny», Russia. \\ (**) State Nature Reserve «Prisursky»,Russia, e-mail: platyscelis@mail.ru \\ Corresponding Author: Alexander B. Ruchin, e-mail: sasha_ruchin@rambler.ru
}

\begin{abstract}
Ruchin A.B., Egorov L.V. - Discovery of Allonyx quadrimaculatus (Schaller, 1783) (Coleoptera Cleridae Clerinae) in Russia.

The paper presents data on a record of Allonyx quadrimaculatus (Schaller) in the Republic of Mordovia (Russia, Central European Territory) and also the whole known information about specimens of the species stored in Russian museums. We discuss the species' distribution which is considered as intermittent. Data on biology of Allonyx quadrimaculatus and description of its newly found habitat are presented.
\end{abstract}

Key Words: Coleoptera, Cleridae, Clerinae, Allonyx quadrimaculatus, new record, Mordovia, Russia.

Cleridae is a family of predatory beetles with a cosmopolitan distribution (GERSTMEIER \& EBERLe, 2011; OpITZ, 2010). Most are predatory as adults and larvae, including some (e.g., Thanasimus Latreille, Enoclerus Gahan) that are important in controlling outbreaks of forest pests such as bark beetles (Curculionidae: Scolytinae) (GAYLORD et al., 2006; BOUCHARD et al., 2017). The world fauna of the Cleridae contains over 3400 valid species and subspecies (Bouchard et al., 2017). The Palearctic fauna of the family is presented by about 215 species (GERSTMEIER, 1998; LÖBL et al., 2007; GERSTMEIER, 2014). In the fauna of Russia there are no less 35 species from 19 genera (RICHTER, 1961; LöBL et al., 2007).

Allonyx Jacquelin du Val is a monotypic clerid genus, belonging to the subfamily Clerinae; the single species being A. quadrimaculatus (Schaller). Prior to its discovery, RICHTER (1961) had supposed that A. quadrimaculatus might occur in the south-western regions of USSR adjoining Europe, however, the first Russian records of $A$. quadrimaculatus were presented by specimens collected in the Bor and Vyksa districts of the Nizhniy Novgorod region (ANUfRIEV, 2004; MoKRousOv, 2008). This species has been included in the Red Data Book of the Nizhniy Novgorod region (2014).

During our entomological research in 2017, a new location of the species in Russia was discovered in the Mordovia State Nature Reserve; its specimens are stored in the collections of Zoological Institute of the Russian Academy of Sciences (St. Petersburg, Russia) (ZIN) and of Zoological Museum of Lomonosov Moscow State University (Moscow, Russia) (ZMMU).

\section{Allonyx quadrimaculatus (Schaller, 1783)}

Material examined - Russia: Nizhniy Novgorod region, Vyksa district, Vyksa town, Vyksunskiy forestry, lower warehouse, 20.VI.2001, 1 ex., collected by Kozin, Mokrousov (ZMMU). Republic of Mordovia, Temnikov district, $17 \mathrm{~km} \mathrm{~N}$ Temnikov city, $54^{\circ} 45.65^{\prime} \mathrm{N}, 43^{\circ} 08.18^{\prime} \mathrm{E}$,
Mordovia State Nature Reserve, quarter 354, 20.V.2017, 1 ex., collected by A.B. Ruchin (stored in ZIN) (Fig. 1). One exemplar collected in the Nizhniy Novgorod region is stored in ZIN collection. Greece, 1 ex., without any else data (ZMMU). Moravia (Brno), 1 ex., Formanek, without any else data (ZMMU).

Distribution (Fig. II) - Austria, Belgium, Croatia, Cyprus, Czech Republic, France, Germany, Greece, Hungary, Italy, Macedonia, Netherlands, Poland, Portugal, Romania, Slovakia, Spain, Switzerland, Turkey (SchmidL, 1997; MajZlan et al., 1999; BAhillo De la Puebla \& LÓPEZ-COLÓN, 2006; LÖBL et al., 2007; KURZELUK, 2012; SARIKAYA \& IBIS, 2016), Russia (Central European Territory).

The range of $A$. quadrimaculatus shows a fragmented distribution with two main continuous part of the species' range located in Western and Central Europe. The Romanian record might represent an isolated surviving population within what might constitute its earlier range across most of Europe. In contrast, the range of species within Russia has a local character, and to date it is limited to the central part of European Russia.

Over the last 30 years, publication of range extension records for A. quadrimaculatus throughout Europe has increased in frequency (SCHMIDL, 1997; MAJZLAN et al., 1999; JAŁOSZYŃSKI et al., 2005; BAHILlO DE LA PUEBLA \& LÓPEZ-Colón, 2006; SANCHez et al., 2015; López VERGARA et al., 2017). According to the map presented by KURZELUK (2012), the range of $A$. quadrimaculatus includes Slovenia, although we did not find any confirmation of this information. KURZELUK (2012) did also not include Greece in the species' range despite earlier inclusion of Greece in the species' range by LöBL et al. (2007), which we confirmed by specimens deposited in the Zoological Museum of Lomonosov Moscow State University. Thus, to date there are three locations of this species in Russia: two records from the Nizhniy Novgorod region and one in the Republic of Mordovia. We predict that the distribution of $A$. quadrimaculatus in Russia may 


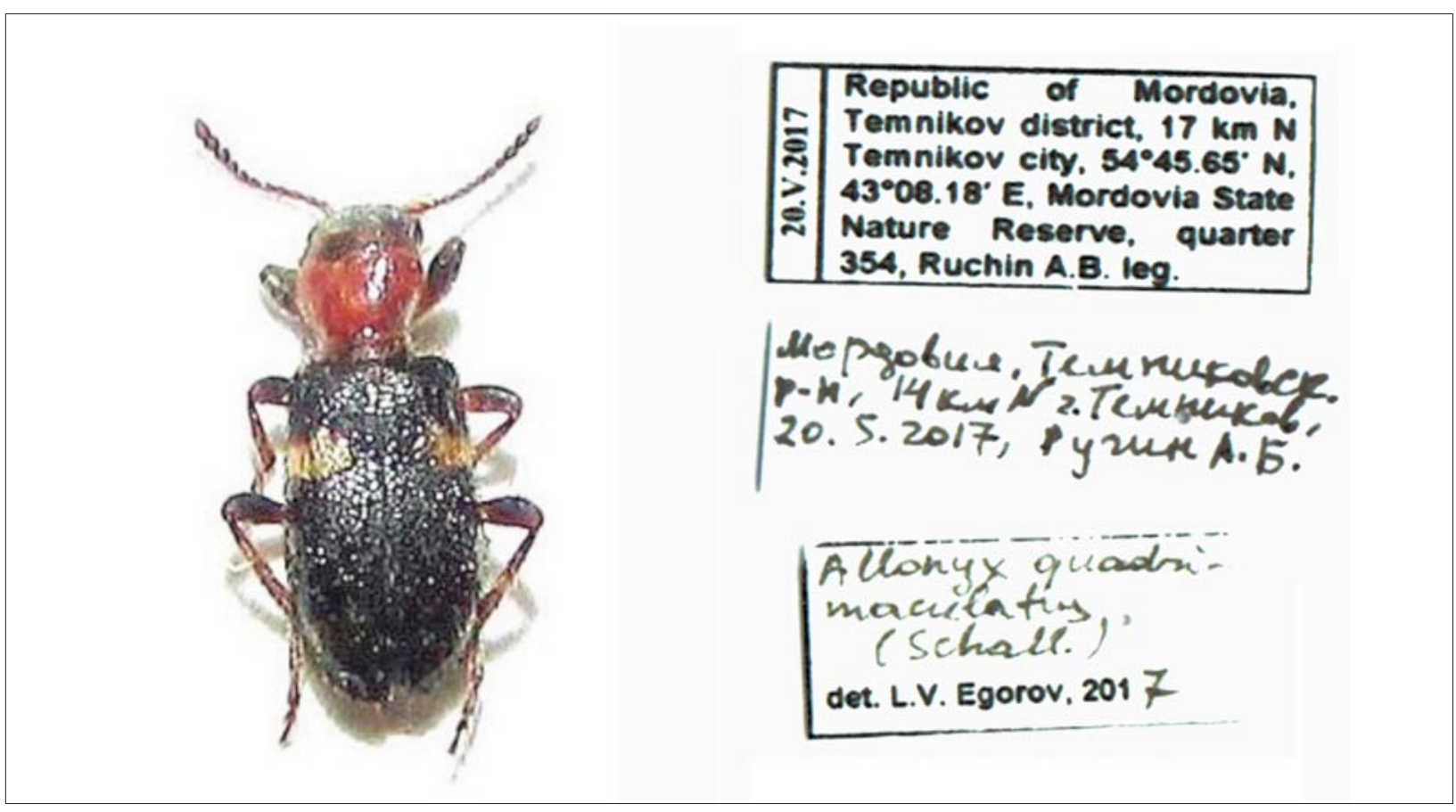

Fig. I-Allonyx quadrimaculatus and labels of the collected specimen.

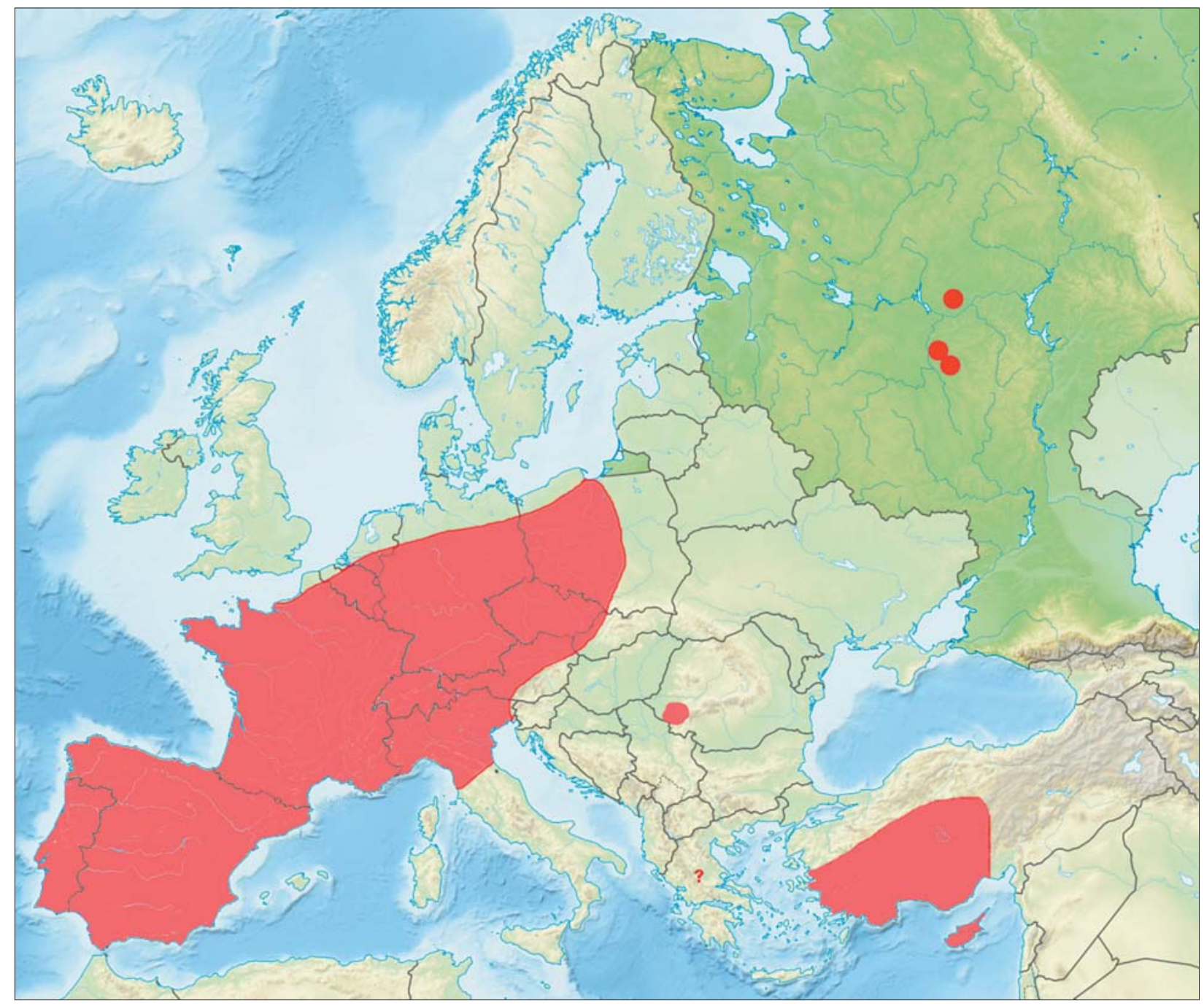

Fig. II - Map of the Allonyx quadrimaculatus distribution in Europe. 
include the Kaliningrad region, bordering Poland, and likely also in regions adjacent to the Nizhniy Novgorod region and the Republic of Mordovia.

BIOTOPES - The habitat of the collection sites of $A$. quadrimaculatus was significantly damaged by wildfire in 2010 , and moderately vigorous surface fire has been observed in the area since. Despite extensive damage to the habitat, some of mature pine trees have remained. Originally the floristical composition of the newly discovered site was pine forest plant community (Pinus sylvestris L.) with green mosses (Pleurozium schreberi Mitt., Climacium dendroides (Hedw.) F. Weber \& D. Mohr, and less commonly Dicranum polysetum Sw.), in the ground layer. Most shrub, herb and ground layer plants were damaged by wildfire during in 2010 (KHAPUGIN et al., 2016a). In 2017 an undergrowth of secondary growth trees (Betula pendula Roth, Populus tremula L.) covered most of the study site area. Among other trees and shrubs Acer platanoides L., Tilia cordata Mill., Sorbus aucuparia L., Quercus robur L., Rubus nessensis Hall were represented by sixyear plants or their stool shoots. Pteridium aquilinum (L.) Kuhn (about 15\%), Viola rupestris F.W. Schmidt (about 10\%) and Convallaria majalis L. (about 5\%) were the most abundant herb layer plants at the study site. Other species of the herb layer included Chamaecytisus ruthenicus (Fischer ex Woloszczak) Klásk., Genista tinctoria L., Calamagrostis epigejos (L.) Roth, Rumex acetosella L., Epilobium angustifolium L., Stellaria media (L.) Vill., Erigeron canadensis L., Milium effusum L., Rubus saxatilis L., Chelidonium majus L., Solidago virgaurea L., Lactuca serriola L., Hieracium umbellatum L., Polygonatum odoratum (Mill.) Druce., Melampyrum pratense L. (ShUGAEV et al., 2015; KHAPUGIN et al., 2016b).

Bionomics - A. quadrimaculatus is a thermophilous species inhabiting trunks and bark of Pinus and Picea trees (KÜHNEl \& MAI, 1985; Mokrousov, 2008; Peres-Otero et al., 2009; SARIKAYA \& IBIS, 2016; López Vergara et al., 2017). The chorology (TAGLIANTI et al., 1992) (EuropeanMediterranean chorotype) and the range limits of $A$. quadrimaculatus in the Western Palaearctic coincides with those of Pinus but the clerid species can be found only in the parts of the tree species range where the mean annual temperatures approaches to sub-Mediterranean values. In Spain, the species is known in mesophilous habitats (GóMEZ DE Dios et al., 2015). Allonyx quadrimaculatus is a predator of various larvae and imago of xylophagous insects plus flatbugs of the genus Aradus Fabricius (RICHTER, 1961; Majzlan et al., 1999; Peres-Otero et al., 2009; SANCHeZ et al., 2015).

The newly found location of $A$. quadrimaculatus in the Republic of Mordovia is not a first unique record of a Coleopteran species in the Mordovia State Nature Reserve. As a result of active investigations of this protected area in recent years, the ranges of a number of Coleoptera species have been specified (LEgALOV et al., 2014; EgOROV \& Shapovalov, 2017; Ruchin \& EgOROV, 2018; TOMASZEWSKa et al., 2018). Such numerous and interesting findings indicate and underline the uniqueness of the forest massif of the Mordovia State Nature Reserve.

\section{ACKNOWLEDGEMENTS}

The authors are grateful to A.A. Gusakov (Zoological Museum of the Lomonosov Moscow State University, Moscow) for the data on Allonyx quadrimaculatus provided from ZMMU collection, A.V. Kovalev and S.V. Andreeva (St. Petersburg, ZIN) for the data on $A$. quadrimaculatus provided from ZIN collection, M.V. Mokrousov for the information about the species' records in the Nizhniy Novgorod region, A.A. Khapugin (Joint Directorate of the Mordovia State Nature Reserve and National Park "Smolny", Saransk) for the description of biotope where the species was found, N.V. Borisova for the photo.

\section{REFERENCES}

ANUfRIEV G.A., 2004 - Rare insect species of the Nizhniy Novgorod region in the fauna of the State Nature Reserve "Kerzhenskiy». In: Natural heritage of Russia: study, monitoring, protection. Togliatti, pp. 13-14. [In Russian].

BAhillo de la Puebla P., LóPez-Colón J.I., 2006 - Los Cléridos de la comunidad de Madrid (Coleoptera, Cleridae). - Graellsia, 62 (número extraordinario): 403418.

Bouchard P., Smith A.B.T., Douglas H., Gimmel M.L., BRUNKE A.J., KAND K., 2017 - Biodiversity of Coleoptera. In: Insect Biodiversity: Science and Society. Vol. 1 (Second Edition). John Wiley \& Sons Ltd., pp. 337-417. DOI 10.1002/9781118945568.ch11

Egorov L.V., Shapovalov A.M., 2017 - On the distribution of a poorly known longicorn beetle, Phymatodes abietinus Plavilstshikov et Lurie, 1960 (Coleoptera, Cerambycidae: Cerambycinae). - Entomological Review, 97 (3): 353-356.

Gaylord M.L., Kolb T.E., Wallin K.F., Wagner M.R., 2006 - Seasonality and lure preference of bark beetles (Curculionidae: Scolytinae) and associates in a Northern Arizona ponderosa pine forest. - Environ. Entomol., 35 (1): 37-47.

GerstmeIER R., 1998 - Checkered beetles, Illustrated Key to the Cleridae and Thanerocleridae of the Western Palaearctic. Margraf Verlag, $300 \mathrm{pp}$.

Gerstmeier R., 2014 - An overview of taxonomy and biology of the Cleridae (Coleoptera, Cleroidea, Cleridae). - Giornale italiano di Entomologia, 13 (59): 481-494.

GerstMeIER R., EBerle J., 2011 - Definition and revision of the Orthrius-group of genera (Coleoptera, Cleridae, Clerinae). ZooKeys, 92: 35-60. https://doi.org/10.3897/ zookeys.92.1157

Gómez De Dios M.Á., Ruiz B.M., Gotarredona Á.C., REVIRIEGo S.R., 2015 - Contribution to the knowledge of the Checkered Beetles (Coleoptera: Cleridae) of Almería (Andalusia, Spain). - Zool. Baetica, 26: 101144.

JAŁoszyński P., Konwerski Sz., MaJewski T., MiŁKOWSKI M., RutA R., ŻUK K., 2005 - Nowe stanowiska interesujących przekrasków (Coleoptera: Cleridae) $w$ Polsce. - Wiad. Entomol., 24 (4): 219-225.

Khapugin A.A., Vargot E.V., Chugunov G.G., 2016a Vegetation recovery in fi redamaged forests: a case study at the southern boundary of the taiga zone. Forestry Studies, 64: 39-50. DOI: 10.1515/fsmu-20160003

Khapugin A.A., Vargot E.V., Chugunov G.G., Shugaev N.I., 2016b - Invasion of alien plants in fire-damaged forests at Southern boundary of the taiga zone. - Forest Systems, 25 (3): eSC13. DOI: 10.5424/fs/201625309461 
KÜHNEL H., MAI A., 1985 - Massenauftreten von Allonyx quadrimaculatus (Col., Cleridae) im Mittelelbegebiet. Ent. Nachr. Ber., 29: 281-282.

KuRZELUK D.K., 2012 - First record of Allonyx quadrimaculatus (Insecta: Coleoptera: Cleridae) in Romania, from the scientific collections of "Grigore Antipa» National Museum of Natural History (Bucharest). - Travaux du Muséum National d'Histoire Naturelle «Grigore Antipa», LV (2): 229-232. DOI: 10.2478/v10191-012-0015-9

Legalov A.A., Egorov L.V., Ruchin A.B., 2014 - First record of Mesauletobius pubescens (Kiesenwetter, 1851) (Coleoptera, Rhynchitidae) in Russia. - Euroasian Entomological Journal, 13 (4): 400. [In Russian].

Löbl I., RolČík J., KolibáČ J., Gerstmeier R., 2007 Family Cleridae Latreille, 1802. In: Catalogue of Palaearctic Coleoptera. Vol. 4. Elateroidea - Derodontoidea Bostrichoidea - Lymexyloidea - Cleroidea - Cucujoidea / Löbl I., Smetana A. (eds.). Stenstrup: Apollo Books, pp. 367-384.

López Vergara M.A., Baena M., Castro Tovar A., 2017 - Contribution to the chorology of some Cleridae in Andalusia (Spain) (Coleoptera, Cleroidea, Cleridae). Boletín de la SAE, 27: 01-09.

Majzlan O., Rychlík I., Deván P., 1999 - A select group of Insects (Coleoptera, Hymenoptera - Specidae, Pompilidae and Vespidae) in study site National nature reserve Čenkovská step in south Slovakia. - Folia faunistica Slovaca, 4: 129-150.

Mokrousov M.V., 2008 - Proposals for the inclusion of selected insect species in the Red Data Book of the Nizhniy Novgorod region. In: Rare species of live organisms of the Nizhniy Novgorod region: collection of working materials of the Commission on the Red Data Book of the Nizhniy Novgorod region. Vol. 1. Nizhniy Novgorod, pp. 25-31.[In Russian].

OpITz W., 2010 - Classification, natural history, phylogeny and subfamily composition of the Cleridae and generic content of the subfamilies (Coleoptera, Cleridae). - Entomologica Basiliensia et Collectionis Frey, 32: 31-128.

Peres-Otero R., Nicolas R., Castro-Garsia A.B., Mansila J.P., 2009 - Xylophagous coleoptera in Pinus pinaster Aiton pine forests in the Galicia region. Comparativ essay 2005-2008. - Bol. San. Veg. Plagas, 35: 571-580.

Red Data Book of the Nizhniy Novgorod Region, 2014 - Vol. 1. Animals. Nizhniy Novgorod: DEKOM, 448 pp. [In Russian].

RICHTER V.A., 1961 - The clerid-beetles (Coleoptera, Cleridae) of the USSR. - Horae Societatis Entomologicae Unionis Soveticae, 48: 63-128.

Ruchin A.B., Egorov L.V., 2018 - Leptura aurulenta (Coleoptera, Cerambycidae), a new record of a very rare species in Russia. - Nature Conservation Research, 3 (1): 88-91. DOI: 10.24189/ncr.2018.003

Sanchez A., Chittaro Y., Monnerat C., 2015 Coléoptères nouveaux ou redécouverts pour la Suisse ou l'une de ses régions biogéographiques. - Entomo Helvetica, 8: 98-111.

SARIKAYA O., IBIS H.M., 2016 - Predatory species of bark beetles in the pine forests of Izmir Region in Turkey with new records for Turkish fauna. - Egyptian Journal Biological Pest Control, 26 (3): 651-656.

Schmidl J., 1997 - Xylobionte Käfer naturnaher Kiefernwälder des Regnitzgebietes Artenspektrum, Naturschutzaspekte und Anmerkungen zur Faunistik und Ökologie ausgewählter Arten (Insecta: Coleoptera). Beiträge zur bayerischen Entomofaunistik, 2: 51-72.

ShugaeV N.I., Khapugin A.A., Vargot E.V., 2015 Analysis of the first changes of vegetation cover of forests in the Mordovia Reserve after the fires of 2010 year. - Proceedings of the Mordovia State Nature Reserve, 14: 396-407. [In Russian].

Taglianti A.V., Audisio P.A., Belfiore C., Biondi M., Bologna M.A., Carpaneto G.M., De Biase A., De Felici S., Piattella E., Racheli T., Zapparoli M., Zoia S., 1992 - Riflessioni di gruppo sui corotipi fondamentali della fauna $W$-paleartica ed in particolare italiana. - Biogeographia, Lavori della Società italiana di Biogeografia (n.s.), 16: 159-179.

TomaszewsKa W., Egorov L.V., Ruchin A.B., Vlasov D.V., 2018 - First record of the genus Clemmus (Coleoptera: Coccinelloidea, Anamorphidae) for the fauna of Russia. - Nature Conservation Research, 3 (3). DOI: $10.24189 /$ ncr.2018.016 